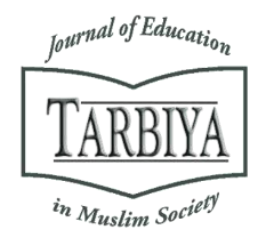

Available online at TARBIYA: Journal of Education in Muslim Society Website:

http://journal.uinjkt.ac.id/index.php/tarbiya

TARBIYA: Journal of Education in Muslim Society, 7(1), 2020, 78-87

\title{
ISLAMIC VALUES IN THE USE OF FOUR STEPS TEACHING MATERIAL DEVELOPMENT (4-STMD) METHOD IN TEACHING STOICHIMETRY MATERIAL
}

\author{
Siti Suryaningsih, Buchori Muslim, Nurul Anjar Wati* \\ Syarif Hidayatullah State Islamic University of Jakarta, Indonesia \\ E-mail: nurulanjarwati1996@gmail.com
}

Received: $08^{\text {th }}$ January 2020; Revised: $24^{\text {th }}$ May 2020; Accepted: $28^{\text {th }}$ June 2020

\begin{abstract}
The Integration of Islam and Science has been applied in several countries both domestically and abroad. The Chemistry Education Study Program has not yet implemented the integration of Islam and science, especially in the stoichiometry concept. Therefore, Chemistry Education at the Syarif Hidayatullah State Islamic University of Jakarta added the Program Learning Outcome (PLO) is in the form of mastering the basic concepts of scientific, Islamic, and Indonesian integration in basic chemistry concept. This study aims to analyze the integration of Islam and science on the stoichiometry concept using the 4-STMD method. The 4-STMD method consists of the selection stage, the structuring stage, the characterization stage, and the reduction stage. The subjects used were 49 students of chemical education class of 2016/2017, one validator of integration experts, and three validators of media experts. The instrument used was in the form of mortar test questionnaire sheets and validation sheets for integration experts and media experts. The result shows that at the selection stage, the determination of the main textbook is the book written by Raymond Chang. In the structuring phase, a draft of the Islamic integrated teaching concept is obtained that ready to be tested. At the characterization, stage have a high level of comprehension test of $80.6 \%$ with the easy category. This shows that the integrated Islamic stoichiometry concept does not need to be carried out at the reduction stage. The results of the stoichiometric material feasibility test were $96.74 \%$ with very decent criteria. The integrated Islamic stoichiometry concept can be used as a reference source in the learning of integrated Islamic chemistry.
\end{abstract}

Keywords: integration of Islam and science; stoichiometry; 4-STMD Method

\section{Abstrak}

Integrasi Islam dan Sains sudah diterapkan dibeberapa negara baik dalam negeri maupun luar negeri. Program Studi Pendidikan Kimia belum menerapkan integrasi islam dan sains terutama dalam materi stoikiometri. Oleh sebab itu, Pendidikan kimia Universitas Islam Negeri Syarif Hidayatullah Jakarta menambahkan Program Learning Outcome (PLO) berupa menguasai konsep dasar integrasi keilmuwan, keislaman, dan keindonesiaan pada materi kimia dasar. Penelitian ini bertujuan untuk menganalisis integrasi islam dan sains pada materi stoikiometri menggunakan metode 4-STMD. Metode 4-STMD terdiri dari tahap seleksi, tahap strukturisasi, tahap karakterisasi, dan tahap reduksi. Subjek yang digunakan adalah 49 mahasiswa pendidikan kimia angkatan 2016/2017, satu validator ahli integrasi, dan tiga validator ahli media. Instrumen yang digunakan berupa lembar angket tes rumpang dan lembar validasi ahli integrasi serta ahli media. Hasil menunjukkan bahwa pada tahap seleksi dilakukan penentuan buku teks utama yaitu buku karangan Raymond Chang. Pada Tahap stukturisasi diperoleh draft bahan ajar terintegrasi keislaman yang siap diujikan. Pada tahap karakterisasi memiliki uji keterpahaman tingkat tinggi sebesar 80,6\% dengan kategori mudah. Hal ini menunjukkan materi stoikiometri terintegrasi keislaman tidak perlu dilakukan tahap reduksi. Hasil uji kelayakan materi stoikiometri sebesar 96,74 \% dengan kriteria sangat layak. Materi stoikiometri terintegrasi keislaman yang dihasilkan dapat digunakan sebagai sumber referensi dalam pembelajaran kimia terintegrasi keislaman.

Kata kunci: integrasi Islam dan sains; stoikiometri; metode 4-STMD

How to Cite: Suryaningsih, S., Muslim, B., Wati, N. A. (2020). Islamic Values in the Use of Four Steps Teaching Material Development (4-STMD) Method in Teaching Stoichimetry Material. TARBIYA: Journal of Education in Muslim Society, 7 (1), 78-87. doi:10.15408/tjems.v7i1.14066.

Permalink/DOI: http://dx.doi.org/10.15408/tjems.v7i1.14066 


\section{Introduction}

Learning applied to State Universities or Private Universities uses a curriculum based on the Indonesian National Qualification Framework (IQF). Steps that can be taken to realize the IQF curriculum are adding Course Learning Outcomes (CLO) to each Study Program. One thing that the Chemistry of Education Study Program can do is add Learning Outcome (LO) in learning in the form of LO Knowledge. The Chemical Education Study Program has not yet implemented integration between science and Islam in its learning. To help realize the vision of the university, the Chemistry Education Study Program integrates Islam and chemistry in the learning process. The integration of Science and Islam can be interpreted as the integration, mixing, and integration of Islam and science (Arifudin, 2016). Sources used in the integration of Islam and science are the Qur'an, the Hadith, Phenomenon, Fiqh, Islamic Cultural History, Morals (Fauzan, 2017; Munadi, 2016; Mufid, 2014; Juknis KSM, 2018). Islamic integration has largely been applied in several countries such as Yemen (Al-Hadabi, 2016), Brunei Darussalam (Hahsim dan Abdullah, 2013), Malaysia (Tajuddin dan Khadafi, 2014), Iran (Bagheri dan Mehr, 2015), and Indonesia (Nuryantini., Karman., dan Holik, 2018; Munir, 2016; Sunhaji, 2018). The application of the integration of science and Islam in Malaysia is at the university level through the International Islamic University Malaysia (IIUM), while in Indonesia it is discussed at the 17th Annual International Conference on Islamic Studies (AICIS) in Jakarta. The existence of AICIS in Indonesia indicates the importance of integration to be carried out.

Integration between Islam and science, in this case, is done on stoichiometry material, because stoichiometry material that is integrated with Islam does not yet exist. The existence of integrated material will make learning that is applied to Islamic nuance not only learning in general. Stoichiometry is the study of the relationship between reagents and the results of reactions in a chemical reaction using the arrow symbol $(\rightarrow)$ (Chang, 2015). Stoichiometry is one part of a basic chemistry course. Where in learning certainly requires sources for learning and the sources used are not only learning resources in general but integrated with Islam.

Research by Nuryantini, Karman, dan Holik (2018) states that the ability of students with a pesantren background does not affect the ability to interpret verses of the Qur'an to the concept of material in depth. This causes important stoichiometric material to be integrated into Islam. The existence of integrated stoichiometry can provide benefits as an integrated Islamic reference source in chemistry learning.

The 4-STMD method is a method that consists of four stages: selection, structuring, characterization, and reduction. The advantage of 4-STMD is a stage that not only selects subject matter from various sources but can also explore the values of students when studying the material being taught. The other three stages are advanced stages that can be useful for developing students in developing they're cognitive, constructing concept structures in students' minds, and characterizing material concepts based on the level of difficulty in order to better understand in understanding the material concepts presented (Hendri, dan Setiawan, 2016).

Based on this, this study aims to analyze the integration between Islam and science in stoichiometry material using the 4-STMD method. 


\section{Method}

The research method used is the Four Steps Teaching Material Development (4-STMD) method. The 4-STMD method is an R\&D development method that consists of the stages of selection, structuring, characterization, and reduction. The selection phase is the stage of determining the main sourcebook by analyzing the Learning Outcome Program (PLO) and Course Learning Outcome (CLO). CLO development begins with analyzing curriculum; curriculum analysis begins with the selection of PLO (Marfu'ah, dan Anwar, 2018). Concept analysis is made to analyze the integration of Islam and chemical concepts in stoichiometry material (Hendri, dan Setiawan, 2016).

The structuring phase is the stage which consists of concept maps, macrostructures, and representations consisting of macroscopic, submicroscopic, and symbolic (Syamsyuri, Anwar, dan Sumarno, 2017). Concept maps are made to make it easier to know what concepts will be taught both integrated and nonintegrated without eliminating the concepts that are in it (Jamal, 2017). The macrostructure outlines a picture of Islamic teaching materials that are integrated. Multiple representations consisting of three levels, namely the macroscopic level, explaining something visible and real, the submicroscopic level is an explanation of the symbolic, and symbolic level in the form of images, symbols, or chemical reactions.

The characterization stage is the stage where the concepts that have been structured are characterized for a comprehension and readability test (Arifin, dan Anwar, 2015). The reduction phase is carried out if there are difficult concepts so that the teaching materials made can be better understood (Ashri, dan Hasanah, 2015).
Subjects used were 2016/2017 chemistry education students who would respond the mortgage given at the characterization stage both in answering question questions and measuring the difficulty of the questions, one integration expert validator who would provide an assessment of Islamic integration and chemical concepts in stoichiometry material, and three validator media experts who will test the feasibility of Islamic integrated stoichiometry material.

Data collection techniques in this study were questionnaire sheets and validation sheets. Questionnaire sheets are used to determine student responses regarding integrated Islamic stoichiometry material. The validation sheet is used to determine the evaluation of integrated Islamic stoichiometry material in terms of integration experts and media experts. The instrument used was a questionnaire instrument in the form of a breakdown type description test and a validation sheet for integration experts and media experts.

There are two data analysis techniques used, namely the mortar test questionnaire sheet, which is processed using the formula:

$$
\begin{aligned}
& \mathrm{K}=\frac{J B}{N} \times 100 \% \\
& \text { Example: }
\end{aligned}
$$

$\mathrm{K}=$ Level of understanding; JB = The average student who answers the concept correctly; $\mathrm{N}=$ The total number of students (Arifin, dan Anwar, 2015)

Evaluation results of integration expert validation sheets using Guttman Scale assessment and media expert validation sheets using Likert Scale assessments. Based on the data obtained, it is processed using the following formula:

$$
\% \text { component : } \frac{\text { Total choice score }}{\text { Maximum score }} \times 100 \%
$$




\section{Results and Discussion}

Based on the method used the data which obtained are as follows:

\section{Selection Stage}

At this stage, several steps were carried out including determining the main book, PLO and CLO analysis, concept analysis, chemical concept analysis, and Islamic integration, validation of integration experts regarding chemical content with Islamic integration (Hendri, dan Setiawan, 2016). The determination of the main book is done by analyzing the concept labels that exist in stoichiometry material. If there are many chemical concepts used in the concept label, the book can be used as the main reference. The main reference in this stage uses a book written by Raymond Chang. PLO analysis derived from the Chemical Education Study Program. Meanwhile, the CLO analysis obtained from the Semester Learning Plan (RPS) in basic chemistry courses on stoichiometry material. The following PLO and CLO can be seen in Table 1.

Table 1. PLO and CLO on Stoichiometry Materials

\begin{tabular}{|c|c|}
\hline PLO & CLO \\
\hline $\begin{array}{l}\text { Mastering the } \\
\text { concept } \\
\text { basic integration } \\
\text { science, Islam, and } \\
\text { Indonesian } \\
\text { in subjects } \\
\text { basic chemistry }\end{array}$ & $\begin{array}{l}\text { - Explain the process of rain in } \\
\text { science } \\
\text { - Analyzing the process of rain with } \\
\text { the equation of chemical reactions } \\
\text { in the perspective of the Qur'an } \\
\text { - Explain the wisdom of rain } \\
\text { - Explain the law of water for } \\
\text { purification } \\
\text {-Explain the history of the discovery } \\
\text { of oxygen } \\
\text { - Concludes the link of Yassin's letter: } \\
\text { 79-80 with the photosynthesis } \\
\text { reaction } \\
\text { - Write the photosynthetic reaction } \\
\text { equation } \\
\text {-Analyzing the process of lightning in } \\
\text { the perspective of the Qur'an } \\
\text { - Explain the suggestion of reading } \\
\text { prayers when hearing lightning in } \\
\text { the perspective of the Hadith } \\
\text {-Explain the limiting reagents in the } \\
\text { perspective of the Qur'an } \\
\text {-Explain the history of the law of } \\
\text { conservation of mass } \\
\text { - Explain the relationship between }\end{array}$ \\
\hline
\end{tabular}

\begin{tabular}{c}
\hline PLO \\
Photosynthesis and respiration with \\
the law of conservation of mass \\
- Explain the history of fixed \\
comparative law \\
-Explain the relationship of the \\
process of human creation with \\
fixed comparative laws \\
-Explain the legal history of volume \\
comparisons \\
-Explain the relationship of the \\
nitrogen cycle to the law of volume \\
comparison
\end{tabular}

At the analysis stage of the concept of chemistry with the integration of Islam, look for the relationship between the concepts to be integrated with sources of Islamic integration such as the Qur'an, Fiqh, Hadith, History, and Phenomena. The following table of chemical concepts with Islamic integration can be seen in Table 2.

Table 2. Chemical Concept with Islamic Integration

\begin{tabular}{|c|c|}
\hline Chemical Concept & $\begin{array}{c}\text { Islamic } \\
\text { Integration }\end{array}$ \\
\hline $\begin{array}{l}\text { Resemblance } \\
\text { Chemical Reaction }\end{array}$ & $\begin{array}{l}\text { The holy Qur'an } \\
\text { Hadith. } \\
\text { Phenomenon, } \\
\text { Fiqih, History }\end{array}$ \\
\hline Limiting Reagents & Al Qur'an \\
\hline Conservation of mass & $\begin{array}{l}\text { History, } \\
\text { Phenomenon }\end{array}$ \\
\hline Law of definite proportions & $\begin{array}{l}\text { History, } \\
\text { Phenomenon }\end{array}$ \\
\hline The Law of Volume Comparison & $\begin{array}{l}\text { History, } \\
\text { Phenomenon }\end{array}$ \\
\hline
\end{tabular}

Based on Table 2, it is known that in the chemical equation concept, the Islamic integration obtained is the Qur'an in the QS. Ar Ruum: 48, Hadith about the benefits of rain in Muslim HR No. 898 and HR Bukhari and Muslim, Natural Phenomena in the form of acid rain, History of the US Ayyub, and Figh in terms of water used for purification. The concept of limiting reagents, integration obtained in the form of orbits as a benchmark in the solar system in QS. Al Anbiya: 33, the law of conservation of mass, the integration of Islam obtained from the 
Phenomenon of Photosynthesis and Respiration, and the history of the law of conservation of mass. In the concept of fixed comparative law the phenomenon obtained in the form of the process of human creation, the history obtained is the history of fixed comparative law, as well as the phenomenon in volume comparison law in the form of the nitrogen cycle and the history of fixed comparative law.

Based on these results, this is following the opinion of Mufid (2014) which states that the source of scientific integration is divided into four namely the Qur'an and the Hadith, the universe, self, and history. Also, according to Fauzan (2017), the integration of science and Islam can be sourced from natural phenomena, the Qur'an and Hadith and based on the (Juknis Kompetisi Sains Madrasah, 2018) shows that it is categorized as integrated chemistry if there are history and culture of Islam, fiqh, creed morals, the Qur' an and the Hadith.

Integration expert integration is done to find out whether the chemical concepts associated with Islamic integration are appropriate or not.

\section{Structuring Phase}

The structuring phase consists of concept maps, macrostructures, and multiple representatives. In making a concept map made by looking at the position or hierarchy in the concept analysis. The making of concept maps aims to make it easier to build knowledge related to the material or concept to be learned (Arifin, and Anwar, 2015). Concept maps are made without eliminating concepts that are not integrated so that they are presented in their entirety which is composed of interrelated concepts (Jamal, 2017; Wiguna, 2014). Furthermore, the macrostructure is an outline description of the structure of the book that serves to find out the clarity of the text and the accuracy of the material structure at various levels (Arifin, dan Anwar, 2015). The macrostructure can be seen in Figure 1:

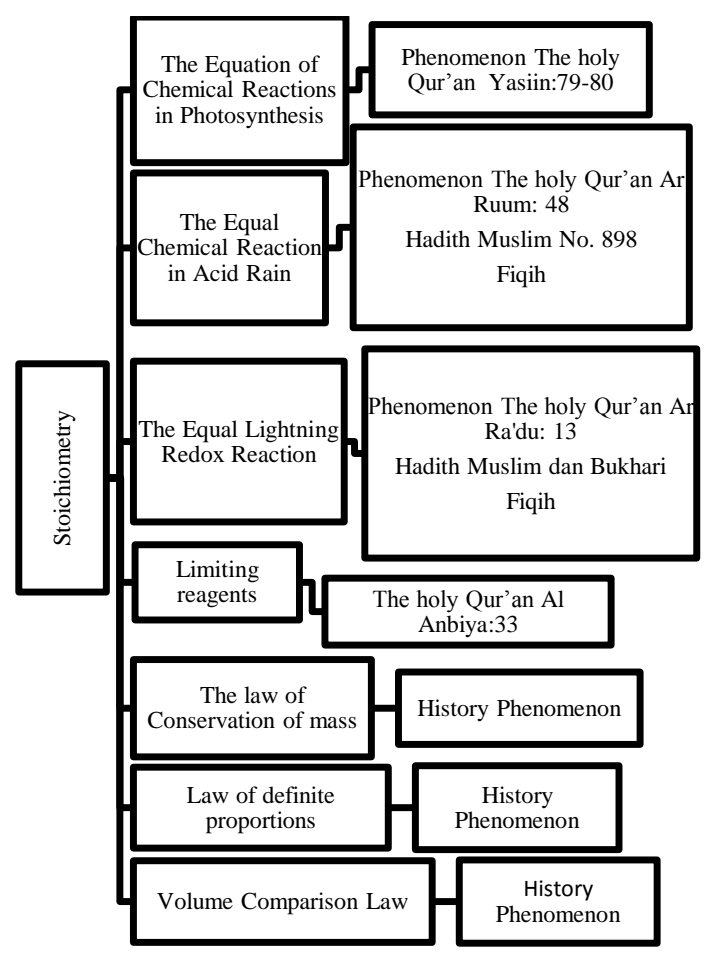

Figure 1. Macrostructure

Figure 1. shows the macrostructure of stoichiometry material. The material is mapped into two-dimensional models, namely the progression dimension and the elaboration dimension. The dimension of progression or vertical dimension is the dimension in the form of the bottom which shows the macro accuracy, while the elaboration dimension or the horizontal dimension (to the right) is the dimension used to achieve the criteria, or explains the criteria of the subject matter (Marfu'ah, dan Anwar, 2018).

Multiple representations are stages consisting of macroscopic, submicroscopic, and symbolic levels. The macroscopic level is real and visible, submicroscopic is used to explain the symbolic level, symbolic is a representative type in the form of images and symbols (Syamsyuri, Anwar, dan Sumarno, 2017). The following multiple representatives can be seen in Table 3: 
Table 3. Multiple Representatives Stoichiometry material

\begin{tabular}{|c|c|c|c|}
\hline Concept & $\begin{array}{l}\text { Macros } \\
\text { copic }\end{array}$ & $\begin{array}{l}\text { Submicros } \\
\text { copic }\end{array}$ & Symbolic \\
\hline $\begin{array}{l}\text { Stoichio } \\
\text { Metry }\end{array}$ & & $\begin{array}{l}\text { Respiration is the } \\
\text { process of } \\
\text { exchanging } \\
\text { oxygen gas (O2) } \\
\text { and carbon } \\
\text { dioxide (CO2) } \\
\text { in the body of } \\
\text { living things. } \\
\text { The equation } \\
\text { that happens is } \\
\text { that glucose will } \\
\text { react with } \\
\text { oxygen to form } \\
\text { water and } \\
\text { oxygen. This } \\
\text { oxygen is used } \\
\text { for breathing. In } \\
\text { addition, in the } \\
\text { process of } \\
\text { respiration, the } \\
\text { law of } \\
\text { conservation of } \\
\text { mass is used } \\
\text { where the mass } \\
\text { before and after } \\
\text { is the same. }\end{array}$ & 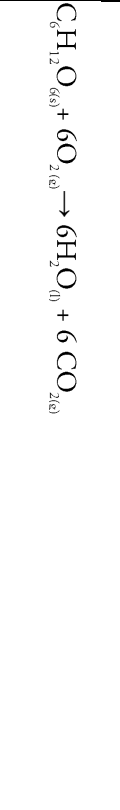 \\
\hline
\end{tabular}

Table 3. shows multiple representations of stoichiometric material. The macroscopic level explains the phenomena that occur in everyday life. The results of multiple representations are then compiled into a draft together with the concept map and macrostructure. The results of the selection stage, concept map, macrostructure, and multiple representatives then form the stoichiometric material. The following is the draft of the stoichiometric material resulting from the structuring process.
Table 4. Sub-Chapter Results of the Structuring Process

\begin{tabular}{|c|c|c|c|c|}
\hline $\begin{array}{l}\text { Chapter } \\
\text { Introduction }\end{array}$ & I & $\begin{array}{l}\text { Chapter II } \\
\text { Chemical } \\
\text { Reaction } \\
\text { Equations }\end{array}$ & $\begin{array}{l}\text { Chapter } \\
\text { III } \\
\text { Limiting } \\
\text { reagents }\end{array}$ & $\begin{array}{l}\text { Chapter } \\
\text { IV } \\
\text { Basic Law } \\
\text { of } \\
\text { Chemistry }\end{array}$ \\
\hline $\begin{array}{l}\text { Stoichio } \\
\text { Metry }\end{array}$ & & $\begin{array}{l}\text {-The Equal } \\
\text { Chemical } \\
\text { Reaction in } \\
\text { Acid Rain } \\
\text {-The } \\
\text { Equation of } \\
\text { Chemical } \\
\text { Reactions in } \\
\text { Photosyn } \\
\text { thesis } \\
\text {-The Equal } \\
\text { Lightning } \\
\text { Redox } \\
\text { Reaction }\end{array}$ & $\begin{array}{l}\text { Limiting } \\
\text { reagents }\end{array}$ & $\begin{array}{l}\text {-The law } \\
\text { of Conser } \\
\text { vation of } \\
\text { mass } \\
\text {-Law of } \\
\text { definite } \\
\text { propor } \\
\text { tions } \\
\text {-Law of } \\
\text { multiple } \\
\text { propor } \\
\text { tions } \\
\text {-Volume } \\
\text { Compa } \\
\text { rison Law } \\
\text {-The law } \\
\text { of Avoga } \\
\text { dro }\end{array}$ \\
\hline
\end{tabular}

\footnotetext{
Characterization Stage

The characterization stage is the stage for conducting field trials as well as the stage for identifying difficult concepts on the teaching materials that have been made. The field trials were conducted by 49 students in 2016/2017. In this stage, a mortar test questionnaire was used with the type of short description questions. In addition to answering questions, students are encouraged to read the chemistry concept excerpts with Islamic integration and answer the level of understanding of the samples presented. The next mortar test instrument can be seen in Figure 2.
} 
In each reaction, there are standards or limits so that a reaction does not exceed the limit, especially in reactants or reactants. Likewise with this universe. The earth rotates on its axis and also surrounds the sun, the moon that surrounds the earth, and so on. This rotation, like the rotation of the planet, which runs continuously and is very orderly in its paths, is called the orbit. Then this orbit is used as a benchmark. The following verses in the Qur'an explains that we may not be excessive.

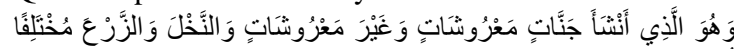

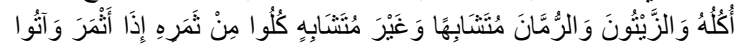

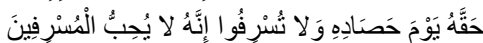

Meaning: $\{141\}$ "It is he who makes gardens that uphold and do not uphold, palm trees, plants of various kinds of fruit, olives and pomegranates that are similar (shape and color) and not the same (taste). eat from its fruits (which are various) when He bears fruit, and exercise its rights on the day of reaping the rewards (by giving it to the poor); and don't overdo it. Verily, Allah does not like exaggerated people. "(Surat al-An'am: 141)

The reactants that were first used up in chemical reactions are called ....

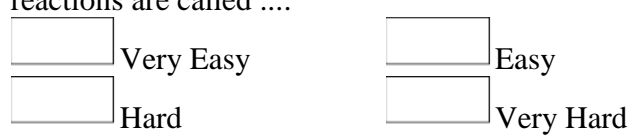

Figure 2. Mortar Test Instrument

The mortar test is tested on the students, the data about comprehension test and readability of the stoichiometry material that has been made, and the concept criteria from the text, following the data of the comprehension test results and the text concept criteria for the mortar test questions.

Based on Table 5. Regarding the comprehension test and concept criteria, it shows that the comprehension data about the questions from the integrated concept label obtained high category, whereas in the identification of the concept it is difficult to obtain the results of 3 easy concept labels and 3 concept labels in the concept very easily. Based on the results of the average percentage of understanding obtained $80.6 \%$. According to Hendri and Setiawan (2016) if the criteria for difficulty level are above 75\%, then the integrated concepts can be categorized as easy.

Table 5. Percentage of Understanding Tests and Concept Criteria

\begin{tabular}{llll}
\hline No & $\begin{array}{l}\text { Understanding } \\
\text { Percentage }\end{array}$ & $\begin{array}{l}\text { Understanding } \\
\text { Level }\end{array}$ & $\begin{array}{l}\text { Concept } \\
\text { Criteria }\end{array}$ \\
\hline $\mathbf{1}$ & 67 & High & Easy \\
$\mathbf{2}$ & 71 & High & Easy \\
$\mathbf{3}$ & 98 & High & Very \\
& & & Easy \\
$\mathbf{4}$ & 94 & High & Very \\
& & & Easy \\
5 & 73 & High & Easy \\
\hline
\end{tabular}

\section{Reduction Phase}

The reduction phase is carried out if the integrated concept is in the difficult category. But based on the results of the study, the concepts obtained in the easy category, so no reduction step is needed.

The feasibility test is carried out by evaluating four aspects, namely language, presentation of material, graphics, and performance (Pusat Kurikulum dan Perbukuan, 2014). The results regarding the due diligence by the validation of media experts can be seen in Table 6.

Table 6. Feasibility test by Ahli Media

\begin{tabular}{lll}
\hline Aspect & Percentage (\%) & Criteria \\
\hline Language & 100,00 & Very Feasible \\
Presentation & 96,67 & Very Feasible \\
Performance & 95,87 & Very Feasible \\
Graphical & 94,44 & Very Feasible \\
\hline
\end{tabular}

Based on Table 6 regarding the validation of media experts on Islamic integrated stoichiometry material obtained a percentage of $100 \%$ from the language aspect so that the enrichment book is very feasible in terms of language. Furthermore, from the aspect of presentation based on the feasibility test conducted, it has a percentage of $96.67 \%$ so that the enrichment book is very feasible in terms of 
presentation. Furthermore, from the performance aspect of $95.87 \%$, it means that the Islamic integrated chemical enrichment book has a very decent title in terms of performance. The results of the last feasibility test were in terms of graphics, based on the results of the feasibility tests conducted obtained aspects of graphics obtained $94.44 \%$ results so that the chemical enrichment book is said to be very feasible in terms of graphics. Overall the book is said to be very feasible based on the assessment rubric of the Ministry of Education and Culture Book which explains that if the assessment percentage is $90 \%<\mathrm{x} \leq 100 \%$ then the book's eligibility criteria are very feasible (Hendri, dan Setiawan, 2016).

Based on the above results, Muslim (2017) states that the integration of Islam in the process of learning chemistry can be done on stoichiometry material. Also, chemistry teachers who are members of AGKI support the integration process in chemical content (Muslim, Agung, dan Al Islam, 2017).

\section{Conclusions}

Based on the results of the research and discussion above, it can be concluded that integrating the stoichiometric material 4-STMD method is used. The method consists of stages of sales, structuring, characterization, and reduction. At the selection stage, Raymond Chang's main source is obtained. At the stage of structuring a draft is obtained regarding teaching materials. In the next step, characterization was obtained by a high level of comprehension test with a percentage of $80.6 \%$ in the easy category. Because the results in the characterization of the concept are relatively easy, so there is no need for a reduction stage. The new thing found in this research is the integrated Islamic stoichiometry material, wherein chemistry there is only stoichiometric material in scientific content only.
Stoichiometry material is material that is very broad in scope and is a basic concept of chemical calculations, but not all concepts can be integrated and only partially so that for further research it is necessary to integrate into other concepts in stoichiometry material supported by reference to the concept of Islamic integration. In addition, the didactic reduction phase needs to be done in order to increase the percentage obtained, and further research is needed to test the use of stoichiometry material in classroom learning.

\section{References}

Al-Hadabi, A. S. (2016). Integrating The Qur'an Verses Into Secondary School ScienceCurriculum Of Yemen: An Islamic Perspective. International Journal of Humanities And Social Science Research , 2, 37-48.

Arifin, dan Anwar, Sjaeful. (2015). Pengembangan Bahan Ajar IPA Terpadu Tema Udara Melalui Four Steps Teaching Material Development. Edusentris: Jurnal Ilmu Pendidikan dan Pengajaran , 2 (1).

Arifudin, I. (2016). Integrasi Sains dan Agama serta Implikasinya terhadap Pendidikan Islam. Edukasi Islamika , 1 (1).

Ashri, Nurul, dan Hasanah, Lilik. (2015). Pengembangan Bahan Ajar IPA Terpadu pada Tema Energi dan Lingkungan. . Prosiding Simposium Nasional Inovasi dan Pembelajaran Sains 2015 (SNIPS 2015).

Bagheri, Abolqasem., Hosseinjanzadeh, Fariborz., dan Mehr, Mohammad Shaygan. (2015). The Consideration of Physics and Chemistry Science in Holy Qur'an. Journal of Applied Environmental and Biological Sciences, 4, 260-265. 
Chang, R. (2015). Kimia Dasar Konsep-Konsep Inti Edisi Ketiga Jilid . Jakarta: Penerbit Erlangga.

Fauzan. (2017). Integrasi Islam dan Sains dalam Kurikulum Program Studi Pendidikan Guru MI Berbasis KKNI. JMIE: Journal of Madrasah Ibtidaiyah Education , 1 (1), $1-13$.

Hahsim, Rosnani dan Abdullah. (2013). Islamization of Human Knowledge in Theory and Practice: Achievements Challenges and Prospects in The IIUM Contect. IIUM Journal of Education Studies , 1 (1), 1-12.

Hendri, S dan Setiawan, W. (2016). Pengembangan Bahan Ajar Tema Gempa Bumi Menggunakan Four Step Teaching Materials Development. Jurnal Pendidikan Fisika Indonesia , 12 (1).

Jamal, N. (2017). Model-Model Integrasi Keilmuan Perguruan Tinggi Keagamaan Islam. Kabilah , 2 (1).

Juknis Kompetisi Sains Madrasah. (2018). Kementrian Agama Islam.

Marfu'ah, S dan Anwar, S. (2018). How to develop SETS-based colloidal system teaching materials? International Conference on Mathematics and Science Education of Universitas Pendidikan Indonesia, 3.

Mufid, F. (2014). Islamic Sciences Integration. QIJIS:Qudus International Journal of Islamic Studies , 2 (1).

Munadi, M. (2016). Integration Of Islam and Science: Study Of TwoScience Pesantrens (Trensain) In Jombang and Sragen. Jurnal Pendidikan Islam , 5 (2).

Munir, S. (2016). Redesigning English For Specific Purposes (ESP) Class: Integrating Language And Islamic Values In
Producing A Textbook. Batusangkar International Conference I, 15-16.

Muslim, B. (2017). Integrating Islamic Perspective in Teaching General Chemistry. 17th Annual International Conference on Islamic Studies.

Muslim, Buchori., Agung, Salamah., \&Al Islam, Ridho Zukhrufian. (2017). Chemistry Teacher's Perception About Integration Of Islam and Chemistry. The $3^{\text {rd }}$ International Conference On Education in Muslim Society

Muslim, B. A. (2017). Chemistry Teacher's Perception About Integration Of Islam and Chemistry. The 3rd International Conference On Education in Muslim Society .

Nuryantini, Ade Yeti., Karman., dan Holik, Abdul. (2018). Integration Science and Religion in Physic Subject: An Analisis in Islamic Higher Education. TARBIYA: Journal of Education in Muslim Society, 5(1), 11-18.

Perbukuan, P. K. (2014). Pedoman Penulisan Buku Nonteks Pelajaran. Jakarta: Kementrian Pendidikan dan Kebudayaan.

Sunhaji. (2018). The Implementation of Integrated Learning in The Islamic Religion Education as to Grow The The Religiosity and Faith of Learners. International Journal of Humanities and Social Science, 6 (11).

Syamsyuri, BS., Anwar, S., dan Sumarno, O. (2017). Development of Teaching Material Oxidation-Reduction Reactions through For Steps Teaching Material Development (4S TMD). International Conference on Mathematics and Science Education (ICMScE) IOP Conf. $S$. 
Tajuddin, Muhammad Saleh dan Khadafi, Muhammad. (2014). A New Paradigm Of Integration Between Scienceand Islam: An Epistemological Framework. Journal of Islam And Science , 1 (1).
Wiguna, F. M. (2014). Kajian Teoritik Tahap Strukturisasi Pengolahan Buku Pengayaan 4-STMD Dilihat Dari Aspek Filosofis, Aspek Psikologis, Aspek Didaktis Dan Aplikasinya Pada Pokok Bahasan Asam Basa. Bandung : UPI. 